ARTICLE

\title{
Size selectivity and optimal soaking time of hoops and traps targeting the blue swimming crab Callinectes arcuatus in Cuyutlan Lagoon, Mexico
}

Tamaño de selectividad y tiempo de remojo óptimo en las capturas de jaiba azul Callinectes arcuatus con artes de pesca jaiberos (aro y trampa) en la Laguna de Cuyutlán, México

\section{Mauricio Salas-Maldonado ${ }^{\circledR 1}$, Elaine Espino-Barr ${ }^{1}{ }^{*}$, Emigdio Marín-Enríquez ${ }^{-2}$, Alberto Bartoleño-Sánchez ${ }^{1}$ and Leonardo Daniel Valdez-Carrazco ${ }^{1}$}

${ }^{1}$ Centro Regional de Investigación Acuícola y Pesquera - Manzanillo, Instituto Nacional de Pesca y Acuacultura, Playa Ventanas s/n, Manzanillo, C.P. 28200, Colima, México

${ }^{2}$ CONACYT-Facultad de Ciencias del Mar, Universidad Autónoma de Sinaloa, Paseo Claussen s/n C.P. 82000, Mazatlán, Sinaloa, México

*Corresponding author: elespino@gmail.com, elaine.espino@inapesca.gob.mx

Resumen.- Se analizó la selectividad de dos tipos de artes de pesca comercial (aros jaibero/arte tradicional y trampas rectangulares de material rígido) que se utilizan para capturar la jaiba azul (Callinectes arcuatus) en la pesquería que opera en la Laguna de Cuyutlán, México. Asimismo, se analizó el efecto del tiempo de remojo de las trampas sobre las tasas de captura y de escape de los organismos. Los resultados del primer experimento sugirieron que la trampa rectangular capturó organismos más grandes, en comparación con el aro jaibero. La estructura del ancho de caparazón fue significativamente diferente entre los artes de pesca evaluados: los aros retuvieron el 63,9\% de tallas < $95 \mathrm{~mm}$ (intervalos entre 40 y $113 \mathrm{~mm}$ ) y las trampas el $40,7 \%$ de tallas $<95 \mathrm{~mm}$ (intervalos entre 49 y $120 \mathrm{~mm}$ ). Los resultados del segundo experimento mostraron que la tasa de captura fue mayor durante las primeras dos horas del tiempo de remojo, y después de la tercera hora la tasa de captura disminuyó. Después de varias horas de tiempo de remojo, los organismos tendieron a escapar. Se encontró que la trampa captura organismos de jaiba azul más grandes que el aro, por lo que es un arte más adecuado en la Laguna de Cuyutlán, México.

Palabras clave: Selectividad, artes de pesca, tiempo de inmersión de la trampa, pesquería artesanal, Laguna de Cuyutlán

Abstract.- The selectivity of two types of commercial fishing gear (crab hoop/traditional gear and rigid rectangular cage traps) targeting blue crabs (Callinectes arcuatus) in Cuyutlan Lagoon, Mexico, was assessed. The effect of soak time on crab catches versus the retention and escape rate of organisms was also evaluated. Results suggested that traps captured larger individuals than hoops. The carapace width of crabs was significantly different between the fishing gears used: $63.9 \%$ of crabs caught with hoops were $<95 \mathrm{~mm}$ (sizes ranged from 40 to $113 \mathrm{~mm}$ ) and $40.7 \%$ of crabs caught with traps were < $95 \mathrm{~mm}$ (range: 49 to $120 \mathrm{~mm}$ ). Results also showed that catch rates were high during the first two hours and decreased after the third hour. The crabs tended to escape after several hours of soak time. The study found that the traps captured larger crabs than the hoops, suggesting that traps are a suitable fishing gear for catching blue swimming crabs in Cuyutlan Lagoon.

Key words: Selectivity, fishing gear, immersion time, artisanal fishery, Cuyutlan Lagoon

\section{INTRODUCTION}

The blue crab Callinectes arcuatus Ordway, 1853 is one of the swimming crabs of the family Portunidae found in the Mexican Pacific (MP); it is an important resource due to its economic value for coastal communities.

Official catch records indicate that the national crab production was 48.6 thousand tons in $2017,64 \%$ of which were captured in the MP. The highest production in the
MP was obtained in Mexico's northern states (Sinaloa and Sonora), where an important small-scale fishery targeting green crabs (C. bellicosus) has been developed (Cisneros-Mata et al. 2014, Rodríguez-Félix et al. 2016, CONAPESCA 2017). The central states of Colima and Jalisco contributed with $\sim 1 \%$ of total national crab catches, which are composed mainly of the blue (C. arcuatus) and brown (C. toxotes) crabs (CONAPESCA 2017). 
In Mexico, the swimming crab fishery is considered a traditional artisanal fishery with great commercial importance. Fishermen construct traps and hoops made of galvanized wire (Gil-López \& Sarmiento-Náfate ${ }^{1}$ ). The operation of these fishing gears is manual and bait is needed to attract the prey (Cisneros-Mata et al. 2014).

In the central part of the MP (in the state of Colima), the crab fishery is monospecific and targets only C. arcuatus. The fishing unit is one fisherman in a small 14 foot-long boat with a 20 horsepower outboard motor, and the main fishing gear was composed of wire hoop of different diameters and mesh sizes. The blue crab $C$. arcuatus fishery is regulated in the MP by federal permits. Rules include the minimum harvest or capture size ( $95 \mathrm{~mm}$ carapace width; MCS) and the protection of ovigerous females under Mexican official standard NOM-039-PESC-2003 (DOF 2006) 2. Authorized fishing gear is also specified in the law; authorized gears include rectangular rigid traps, hoops, spoon nets, and metallic hooks.

Knowledge of the specific size selectivity of commercial fishing gears is vital for the proper management of a given commercial fishery. Management tools should take into account information on fishing intensity and the size at which organisms are susceptible to being caught by the fishing gear (Millar 1992). Another important point to take into account when evaluating fishing gears is the design. Physical parameters (such as size and trap volume) and operational parameters (such as soak time or immersion time) directly influence the catch efficiency of fishing gears (Vazquez-Archdale et al. 2007).

The objectives of the present study were to describe the size structure of the captured blue crab population based on carapace width. The selectivity of two fishing gears (hoops and traps) was estimated and the effect of trap soak time on the catch rate of blue crabs in the Cuyutlan Lagoon, Mexico.

\section{MATERIALS AND METHODS}

\section{STUdY AREA}

Cuyutlan Lagoon, Mexico (CL) is a coastal lagoon. It is located on the Eastern Pacific Ocean between $18^{\circ} 53^{\prime} \mathrm{N}$ and $19^{\circ} 03^{\prime} \mathrm{N}$, and between $104^{\circ} 00^{\prime} \mathrm{W}$ and $104^{\circ} 20^{\prime} \mathrm{W}$. It is connected to the ocean through three artificial channels: Tunnel, Ventanas, and Tepalcates. The average air temperature ranges from $26.1{ }^{\circ} \mathrm{C}$ in December to $32.6{ }^{\circ} \mathrm{C}$ in July. Salinity varies from 28.2 to 35.4 (Sosa-Ávalos et al. 2013). The maximum depth in the lagoon is $2 \mathrm{~m}$ and dredging activities are carried out periodically to maintain a depth of $\sim 15 \mathrm{~m}$ in the channels near the sea.

\section{SELECTIVITY AND SIZE STRUCTURE}

Two fishing gears were tested simultaneously between May and December 2016: 10 hoops of traditional design constructed with monofilament net, with $76 \mathrm{~mm}$ diagonal mesh size, fixed to a circular ring $35 \mathrm{~cm}$ in diameter, and 10 rectangular traps without escape windows, consisting in a rigid rectangular structure made from plasticized wire. The dimensions of the $2.5 \mathrm{~cm}$ mesh size rectangular traps were 62 $\mathrm{cm}$ long, $62 \mathrm{~cm}$ wide and $36 \mathrm{~cm}$ high; there were two $10 \cdot 20 \mathrm{~cm}$ entrances at the sides in the upper part of the trap, and one $5 \cdot 20 \mathrm{~cm}$ entrance at the end of the interior of the trap. There was a $35 \cdot 10 \mathrm{~cm}$ bait container in the middle trap, with 1.3 $\mathrm{cm}$ mesh size. A polyethylene cord ( $3 \mathrm{~mm}$ ) was tied from the trap to a buoy (Fig. 1). The hoops were used according to the traditional practices of local fishermen, and the traps were employed following Nevárez-Martínez et al. (2008) and Cisneros-Mata et al. (2014). The experiment was carried out under the assumption that the mesh size of the hoops does not affect catchability, as suggested by Gil-López (2009).

Sailfish (Istiophorus platypterus) skin was used as bait (50 $\mathrm{g}$ tied at the center of the hoop, renewed every hour, and $300 \mathrm{~g}$ in each rectangular trap inside the bait container). The process lasted the entire night, simulating a fishing maneuver employed by local fishermen. The fishing gear was then lowered to the bottom of the lagoon (from 0.6 to $1.2 \mathrm{~m} \mathrm{depth}$ ) and placed in pairs (hoop and trap) $5 \mathrm{~m}$ away from each other in random order (Miller 1979), assuming that hoops and traps would be exposed to the same density of crabs and physical environment. The hoops were checked every $15 \mathrm{~min}$, simulating the operational times of local fishermen, and the traps were checked every hour, for a total of four hours for both gears. The crabs captured in each gear were counted, the sex was identified (by direct observation), and the individuals were measured (carapace width, in $\mathrm{mm}$ ).

Two tests were used (Kolmogorov-Smirnov \& Bartlett's) to evaluate the normality of the data and homoscedasticity of the variance, respectively (Zar 1996). A Chi-Square test $\left(\chi^{2}\right)$ was used to test for possible statistical differences between gears in the sex ratio and in the percentage of crabs that were larger in carapace width $(\mathrm{CW})$ than the minimum legal capture size (MCS) (Daniel 1991). Kolmogorov-Smirnov and Bartlett's tests suggested that data were not normally distributed and that the sizes of the two sexes were not homoscedastic; therefore, a Kruskal-Wallis test was used.

\footnotetext{
${ }^{1}$ Gil-López HA \& S Sarmiento-Náfate. 2001. Algunos aspectos biológicos y pesqueros de las jaibas (Callinectes spp.) en el sistema lagunar Mar Muerto, Oaxaca-Chiapas. Informe Técnico (Documento Interno). SAGARPA, INP, CRIP-Salina Cruz, Oaxaca, 41 pp.
}

${ }^{2}$ DOF. 2006. Norma Oficial Mexicana NOM-039-PESC-2003. Pesca responsable de jaiba en aguas de jurisdicción federal del litoral del Océano Pacífico. Especificaciones para su aprovechamiento. Diario Oficial de la Federación, México, 26 de julio de 2006. 

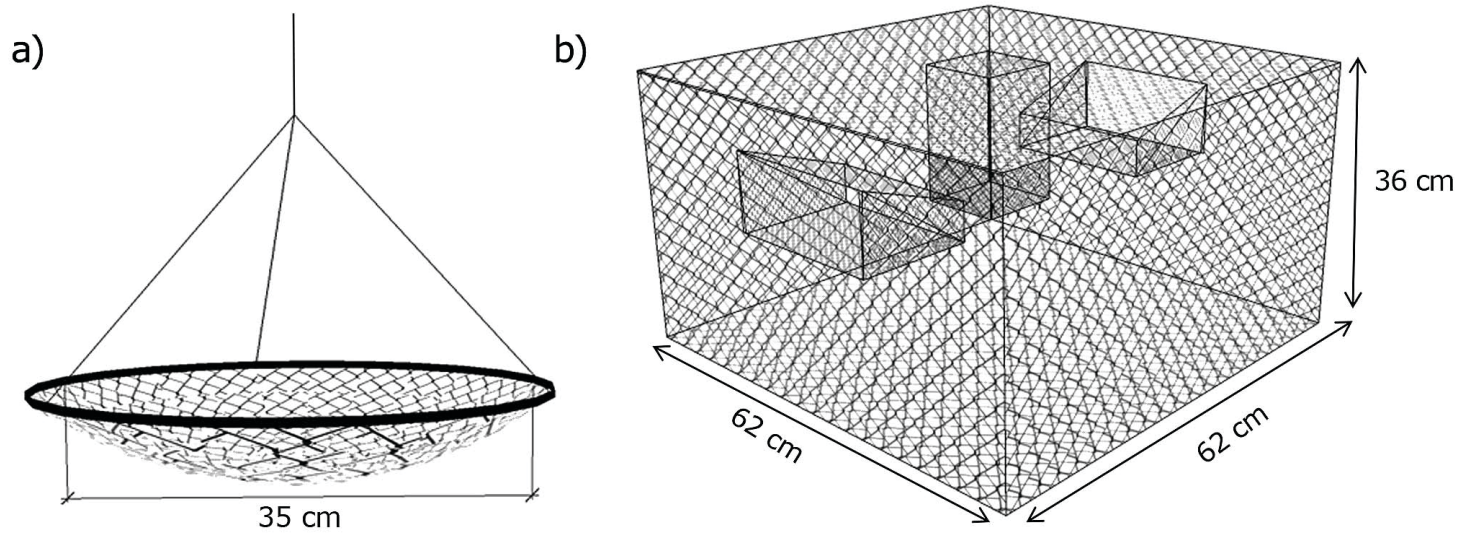

Figure 1. Fishing gears used to catch blue crabs in Cuyutlan Lagoon, Mexico: a) crab hoop, b) rectangular type trap / Características físicas del arte de pesca para la captura de la jaiba en la Laguna de Cuyutlán, México: a) aro jaibero, b) trampa tipo rectangular

The CW data were grouped into $5 \mathrm{~mm}$ size classes and the Kruskal-Wallis test was used to detect possible differences in sexual proportions (Zar 1996). A selectivity analysis was performed to compare the selectivity curves of the two gear types (Nevárez-Martínez et al. 2008), defined by the symmetric logistic function (Stewart \& Ferrell 2003):

$$
r(C W)=\left[\exp ^{(a-b \cdot C W)} /\left(1+\exp ^{(a-b \cdot C W)}\right)\right]
$$

Where: $\mathrm{a}$ and $\mathrm{b}$ are the logistic function parameters that characterize the selectivity curve (Millar \& Fryer 1999). The logistic model was fitted using the non-linear least-squares algorithm of the $n l s$ function in the R environment (R CoreTeam 2020). This allowed us to obtain the estimate of the selection ogive $C W_{50 \%}$; that is, the $\mathrm{CW}$ value where $50 \%$ of organisms are retained in the fishing gear. The confidence intervals of the logistic model parameters were estimated using the confint function in R (R Core-Team 2020) and used to estimate $95 \%$ confidence intervals of the $C W_{50 \%}$. The selection range $(S R)$ was obtained by calculating the difference between $C W_{75 \%}$ and $C W_{25 \%}$, as follows:

$$
\begin{gathered}
C W_{50 \%}=-a / b \\
C W_{75 \%}-C W_{25 \%}=(2 \cdot \operatorname{Ln}(3) / b)
\end{gathered}
$$

\section{OPTIMAL SOAK TIME}

The second experiment was carried out from March to November 2017, at the same study site (CL) to determine the effect of trap soak time on catch rates, trap saturation, and escape rates of blue crabs. Sampling consisted of a completely randomized block experimental design (Montgomery 1984), comprising five traps set $20 \mathrm{~m}$ from each other in a line. Once per month, traps were installed to catch (soaked) from 8:00 pm to 4:00 am, for a total of eight hours. The treatments for this experiment consisted of eight soak-time intervals; that is, each trap was checked every hour, the organisms were counted and left in the traps, and the trap was put back in the water. This procedure was repeated until completing eight hours of operation. The experiment was performed once a month over nine months.

A model was used to determine the effect of soak time; the relationship between catch rates and soak times was expressed using the equation suggested by Zhou \& Shirley (1997):

$$
C_{t}=a b+a(t-b) \exp ^{-c t}
$$

Where: $C_{t}$ was the catch at time $t$, and the parameters $a$, $b$, and $c$ were estimated using non-linear least squares via the $n l s$ function in the $\mathrm{R}$ environment (R Core-Team 2020). The product of $a$ and $b$ is the asymptotic capture after an infinite soak time and the capture is zero at time $=0$. Parameters $a$ and $c$ depend on the local density of the organisms and the entrance rate to the trap, and $c$ reflects the escape probability (Zhou \& Shirley 1997). The optimum soak time was the time (in hours) where the curve of the fitted model predicted a number of retained individuals that was lower than the overall mean of the retained blue crab individuals. For the particular case of this model, the algorithm failed to converge and the confidence intervals of the parameters could not be estimated with the confint function of $\mathrm{R}$ ( $\mathrm{R}$ CoreTeam 2020), presumably because the minimum tolerance of the algorithm was not satisfied, a problem associated with low sample sizes. To estimate the confidence intervals of the optimum soak time, $95 \%$ confidence bands were created around the model fit by multiplying the residual standard error of the model by 1.96 and adding/subtracting the result to the model fit. 


\section{ReSUlTS}

\section{SELECTIVITY AND SIZE STRUCTURE}

Ten hoops and 10 traps were used in the first experiment. A total of 601 crabs were captured with hoops and 1,048 with traps, for a total of 1,649 crabs.

There were significant differences in the size structure of crabs between the two gear types $\left(\mathrm{H}_{(1,1649)}=105.05, P<\right.$ $0.001)$. Hoops retained smaller individuals ( $\mathrm{CW}$ ranging from 40 to $113 \mathrm{~mm}$, mean $=85 \mathrm{~mm})$ than traps $(49-120$ $\mathrm{mm}$, mean= $92 \mathrm{~mm}$ ) (Fig. 2).

A total of 289 females and 1,360 males were caught, with significant differences in sexual proportion $(\mathrm{M}: \mathrm{F}=$ $\left.4.7: 1.0 ; \chi^{2}=0.079, \mathrm{DF}=1, P<0.05\right)$. The average $\mathrm{CW}$ of females was $80 \mathrm{~mm}$ ( $\pm 12 \mathrm{~mm}$ standard deviation, SD), ranging from 54 to $115 \mathrm{~mm}$. The average $\mathrm{CW}$ of males was $91 \mathrm{~mm}$ ( $\pm 11 \mathrm{~mm} \mathrm{SD})$, ranging from 40 to $120 \mathrm{~mm}$. CW data were not normally distributed $(D=0.096197$, $P<0.05)$; the Kruskal-Wallis test suggested significant differences in $\mathrm{CW}$ between the two sexes: males were larger than females $\left(\mathrm{H}_{(1,1649)}=195.82, P<0.001\right)$ (Fig. 2).
For the two sexes combined, hoops captured a higher percentage of sublegal sizes $(63.9 \%)$, females $(88.7 \%)$, and males $(56.8 \%)$ than traps. On the other hand, traps retained fewer sublegal-sized organisms $(40.7,75.6$, and $34.6 \%$, respectively) and more legal-sized organisms (59.3, 24.4 , and $65.4 \%$, respectively), with significant differences between legal and sublegal sizes $\left(\mathrm{H}_{(1,601)}=46.404, P=\right.$ 9.62 $\cdot 10^{-12}$ for hoops and $\mathrm{H}_{(1,1048)}=35.912, P<0.001$ for traps ) (Table 1).

Table 1. Catch percentages according to carapace width (CW) minimum legal size ( $C W \geq 95 \mathrm{~mm}$ ) by gear and sex / Porcentaje de captura de acuerdo al tamaño legal del ancho de caparazón ( $C W \geq 95$ $\mathrm{mm}$ ) entre artes de pesca y por sexos

\begin{tabular}{lcccc}
\hline \multirow{2}{*}{ Group } & \multicolumn{2}{c}{ Hoop } & \multicolumn{2}{c}{ Trap } \\
\cline { 2 - 5 } & $\begin{array}{c}\mathrm{CW}<95 \\
(\mathrm{~mm})\end{array}$ & $\begin{array}{c}\mathrm{CW} \geq 95 \\
(\mathrm{~mm})\end{array}$ & $\begin{array}{c}\mathrm{CW}<95 \\
(\mathrm{~mm})\end{array}$ & $\begin{array}{c}\mathrm{CW} \geq 95 \\
(\mathrm{~mm})\end{array}$ \\
\hline Combined & 63.90 & 36.10 & 40.70 & 59.30 \\
Females & 88.70 & 11.30 & 75.60 & 24.40 \\
Males & 56.80 & 43.20 & 34.60 & 65.40 \\
\hline
\end{tabular}

a)

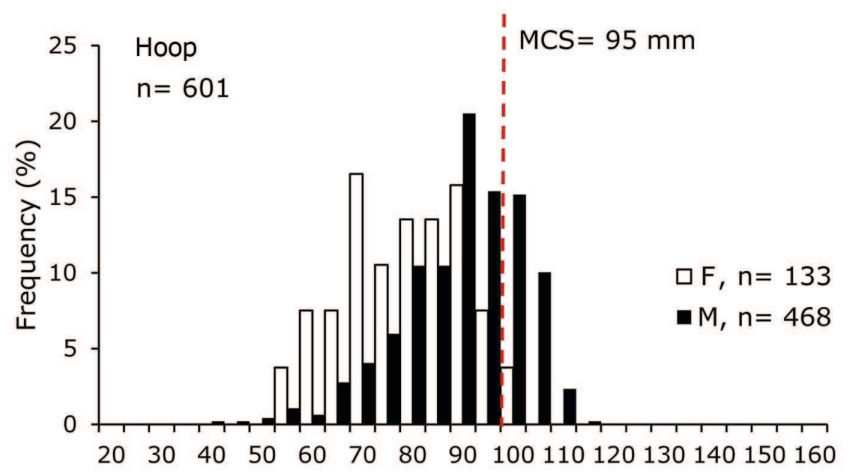

b)

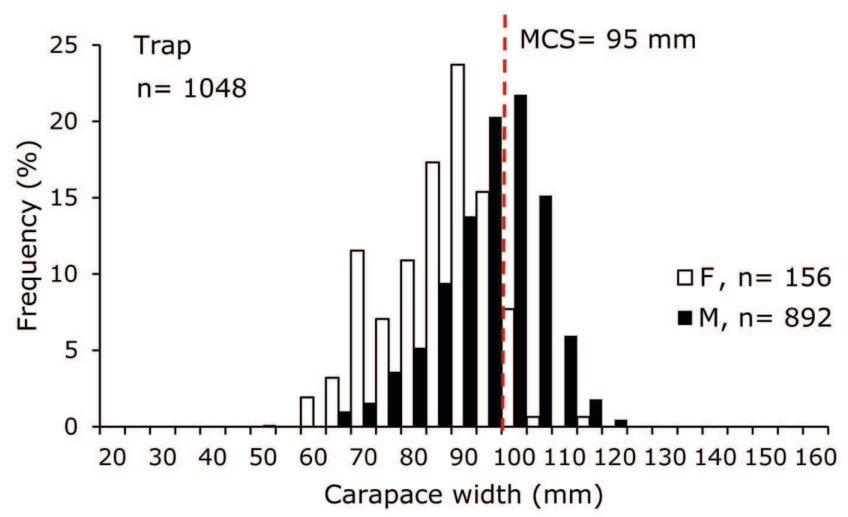

Figure 2. Carapace width (CW) of blue crab (Callinectes arcuatus) males (M) and females (F) captured in Cuyutlan Lagoon, Mexico, using a) hoops and b) traps. Dashed line represents the minimum legal capture size (MCS) of 95 mm / Ancho de caparazón (CW) de hembras (F) y machos (M) de la jaiba azul (Callinectes arcuatus) capturados en la Laguna de Cuyutlán, México con: a) aros y b) trampas. La línea punteada representa el tamaño mínimo legal de captura (MCS) de $95 \mathrm{~mm}$ 
The 25, 50, and $75 \%$ selectivity ogive estimations $\left(C W_{25 \%}, C W_{50 \% \text {, }}\right.$ and $\left.C W_{75 \%}\right)$ and the SR of the two fishing gears showed that traps caught larger organisms $\left(\mathrm{CW}_{50 \%}=\right.$ $91.72 \mathrm{~mm}$; $95 \%$, C.I. $91.65-91.78 \mathrm{~mm})$ than hoops $\left(C W_{50 \%}=\right.$ $85.28 \mathrm{~mm}$; $95 \%$, C.I. $85.17-85.38 \mathrm{~mm})$. The $S R$ was 18.60 $\mathrm{mm}$ for hoops, with sizes ranging from 76 to $95 \mathrm{~mm}$, whereas the $S R$ was $14.50 \mathrm{~mm}$ for traps, with sizes ranging from 85 to $100 \mathrm{~mm}$ (Table 2, Fig. 3).

\section{OPTIMAL SOAK TIME}

The retention rate of the five traps was higher during the first hour in the water, with values of $15,25,32,52$, and 60 organisms. During the second hour, the catch rate increased in only two traps ( 6 and 8 individuals), and there was a reduction in the other 3 traps (from 60 to 7 individuals, 32 to 19 individuals, and 25 to 5 individuals, respectively). An increase was observed in three traps during the third hour (16, 36, and 31 organisms), and individuals escaped from two traps (from 60 to 11 individuals and from 21 to 10 individuals). There was an increase in catches in two traps during the fourth hour (from 31 to 48 individuals and from 10 to 43 individuals), whereas captures decreased in the other three traps, with final values of $34,33,7$, and 5 individuals. The first negative records occurred after the
Table 2. Parameters of the logistic selectivity function modeled for blue crab (Callinectes arcuatus) caught in hoops and traps in Cuyutlan Lagoon, Mexico / Parámetros de la función logística de la selectividad en aros jaiberos y trampas de la jaiba azul (Callinectes arcuatus) capturada en la Laguna de Cuyutlán, México

\begin{tabular}{|c|c|c|c|c|c|c|c|}
\hline Fishing gear & $a$ & $b$ & $P$ & $\begin{array}{c}\mathrm{CW}_{25 \%} \\
(\mathrm{~mm})\end{array}$ & $\mathrm{CW}_{50 \%}(\mathrm{~mm})$ & $\begin{array}{c}\mathrm{CW}_{75 \%} \\
(\mathrm{~mm})\end{array}$ & $\begin{array}{c}\text { SR } \\
(\mathrm{mm})\end{array}$ \\
\hline Hoop & 10.70 & 0.13 & 0.47 & 76.00 & $\begin{array}{c}85.28 \\
(85.17-85.38)\end{array}$ & 95.00 & 18.60 \\
\hline Trap & 15.00 & 0.16 & 0.57 & 85.00 & $\begin{array}{c}91.72 \\
(91.65-91.78)\end{array}$ & 100.00 & 14.50 \\
\hline
\end{tabular}

*Values between brackets represent $95 \%$ confidence intervals

fifth and sixth hours; that is, between 2 and 21 organisms escaped. There were no catches in the seventh and eighth hour, and the escapes were higher (Fig. 4).

Results of the effect of trap soak time showed that the higher catch rates occurred in the first $\sim 4$ hours. Catch rates were lower than the mean at around 4.2 hours, with estimated 95\% confidence intervals of 2.9-6.9 hours), suggesting that the optimal soak time is between $\sim 3$ and 4 hours. Obtained parameters can reflect the local density of the organisms, a high probability in the entrance and escape rates $(a=313.80, b=0$, and $c=0.71)$ (Fig. 5).

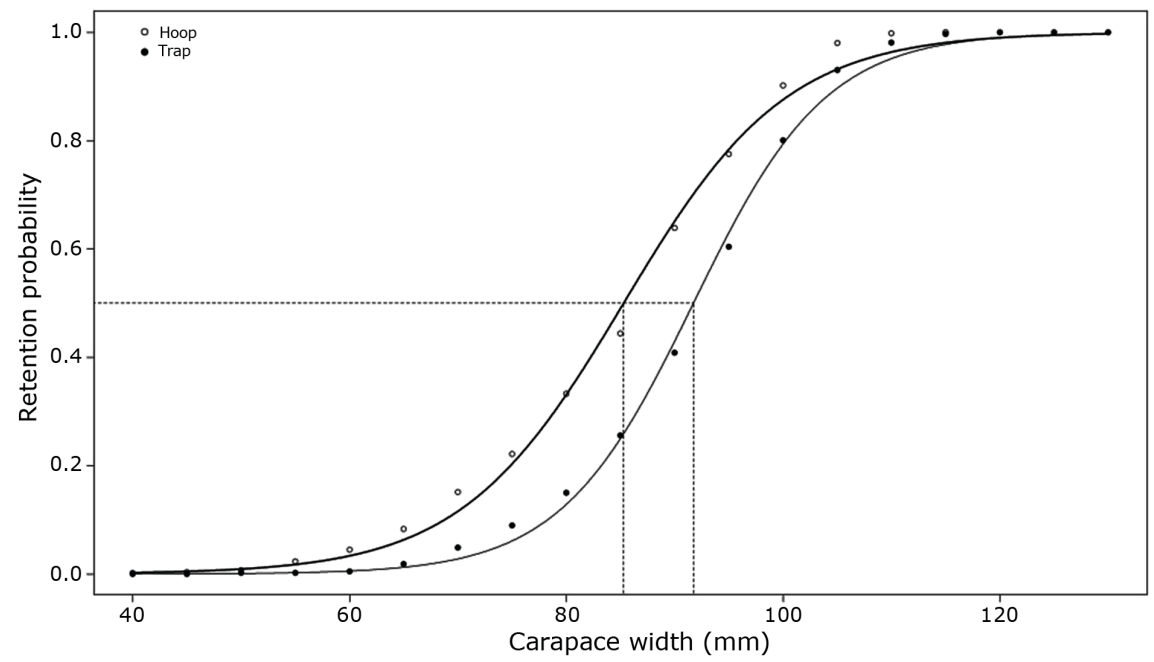

Figure 3. Observed (dots) and predicted mean (line) retention probability of the blue crab (Callinectes arcuatus) using hoops and traps; (dashed lines represent the selectivity for hoops $\mathbf{C W}_{\mathbf{5 0 \%}}=\mathbf{8 5 . 2 8} \mathbf{m m}$ and traps $\mathbf{C W}_{\mathbf{5 0 \%}}=\mathbf{9 1 . 7 2} \mathbf{m m}$ ) / Valores observados (línea punteada) y media calculada (línea) de la probabilidad de retención de la jaiba azul (Callinectes arcuatus) por el aro y la trampa; (la línea punteada representa la estimación de la selectividad del aro $\mathrm{CW}_{50 \%}=85,28 \mathrm{~mm}$ y la trampa $\mathrm{CW}_{50 \%}=91,72 \mathrm{~mm}$ ) 


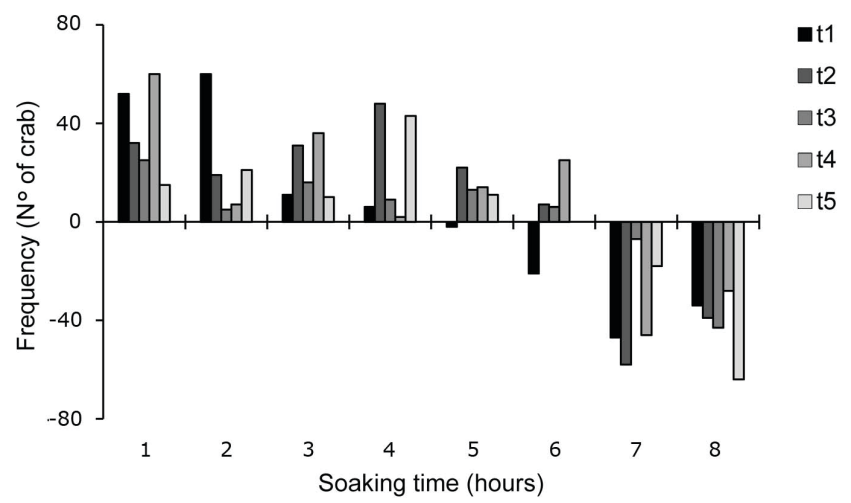

Figure 4. Retention rates of the blue crab (Callinectes arcuatus) in soaking traps. Different tones of gray depict the different trap replicates used in the experiment (t1-t5) / Tasa de retención de la jaiba azul (Callinectes arcuatus) en las trampas sumergidas. Los distintos tonos de gris representan las diferentes réplicas de trampas (t1-t5)

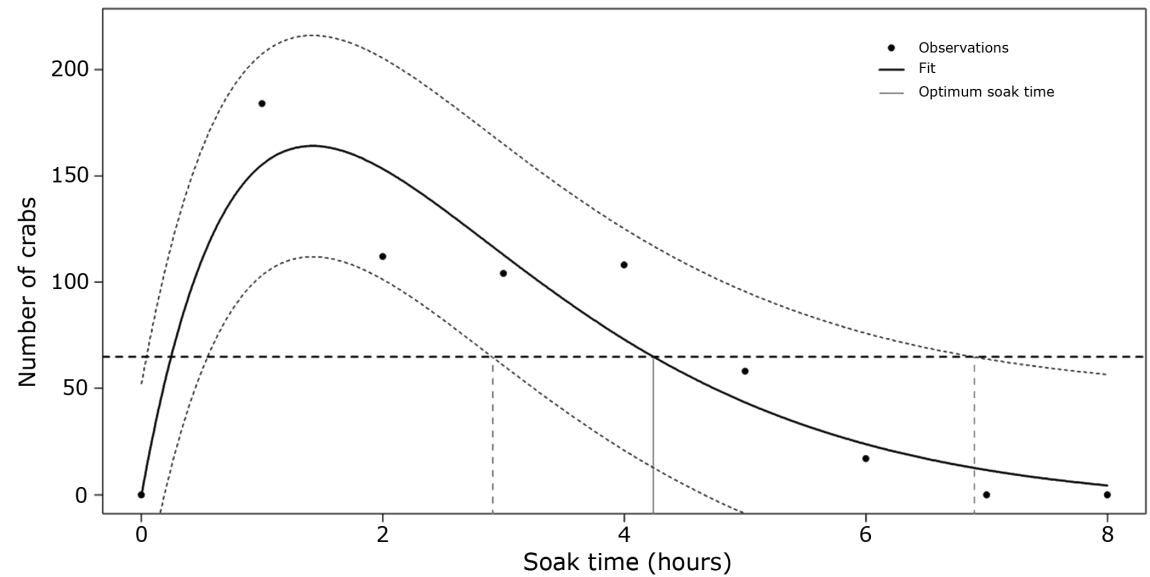

Figure 5. Number of blue crabs (Callinectes arcuatus) retained during different trap soak times. The continuous vertical line depicts the optimum soak time and the dashed vertical lines depict the confidence intervals of the optimal soak time / Número de jaibas azules (Callinectes arcuatus) retenidas en las trampas a través del tiempo de remojo. La línea continua vertical muestra el tiempo óptimo de remojo, y las líneas punteadas verticales muestran los intervalos de confianza del tiempo óptimo de remojo

\section{Discussion}

This study estimated crab catches using two fishing gears, with significant differences between $\mathrm{CW}$. These results can help improve the management of the C. arcuatus fishery. For example, if the MCS (minimum capture or harvest size) of the blue crab (C. arcuatus) is $\geq 95 \mathrm{~mm}$ $\mathrm{CW}$ [according to the regulation NOM-039-2003 (DOF $\left.2016)^{2}\right]$, results suggest that hoops catch a high percentage of crabs measuring less than the MCS (more than $63.9 \%$ of the total catch), whereas this percentage was lower in traps ( $40.7 \%$ of total catch), with significant differences between the two fishing gear types. This same effect of obtaining organisms smaller than the MCS with hoops was reported by Estrada-Valencia (1999) in the same study area with the same species, reporting catch sizes from $77 \mathrm{~mm}$ to 95 mm CW. Gil-López (2009) found first capture sizes of 92 $\mathrm{mm} \mathrm{CW}$ with hoops and nets with mesh sizes of 3 and 5 inches, and traps with 2.3 inches, used in the crab fishery of the Mar Muerto lagoon system in Oaxaca and Chiapas, in southwestern Mexico.
Parameters of the selectivity curves for each gear indicated that the hoops retained organisms with a broad spectrum of $\mathrm{CW}$ that covered values lower than the MCS $\left(C W_{25 \%}=76.00 \mathrm{~mm}, C W_{50 \%}=85.28 \mathrm{~mm}, C W_{75 \%}=95.00\right.$ $\mathrm{mm}$, and $S R=18.60 \mathrm{~mm}$ ). The main gears used by these fishermen were hoops, and our field experience indicates that fishermen routinely select larger sizes and liberate small individuals and females. Nevertheless, such physical maneuvers could sometimes damage specimens through the loss of appendages, with possible repercussions on their development (Rodríguez-Domínguez et al. 2015). On the other hand, despite the fact that experimental traps did not have escape windows, larger crabs were caught $\left(C W_{25 \%}=85.00 \mathrm{~mm}, C W_{50 \%}=91.27 \mathrm{~mm}, C W_{75 \%}=100.00\right.$ $\mathrm{mm}$, and $S R=14.50 \mathrm{~mm}$ ) than when using hoops, and crabs would probably escape once they deplete the bait. The size structure of captured crab individuals changed throughout the year in a homogenous way for both gears, although traps always captured larger crabs. Similar results have shown that traps result in significant improvements 
in selectivity and efficiency in time (Boutson et al. 2009) and it is possible that the traps retained larger organisms because the presence of larger individuals inside the trap intimidates and threatens smaller organisms, which prevents them from entering (Miller 1979, VazquezArchdale et al. 2007). This factor characterizes traps as a versatile fishing gear with an acceptable fishing power in terms of catch yields and size selection, and a good option for fishermen to catch crabs that are larger than the MCS. It is important to be aware that the target species and their desired sizes in the catch depend on several factors, including trap design and bait (Miller 1990, VazquezArchdale et al. 2007). In our study, the design of the trap was the type used in northern states of the MP and the bait was supplied by the crab fishermen in the CL, so that our results could represent an advantage among fishermen (obtaining larger crabs). Once the fishermen start to use traps, they have to include escape windows to lower the percentage of retained individuals of sublegal sizes. Forms and sizes of the escape windows have been described by De la Rosa-Pacheco \& Ramírez-Rodríguez (1996), Herbert et al. (2001), Nevárez-Martínez et al. (2008), Cisneros-Mata et al. (2014). There has been evidence of the operational profitability of crab traps in other fishing areas in northern Mexico (Cisneros-Mata et al. 2014), which supports the results obtained in this study. In addition to documenting some important aspects of the selectivity of the fishing gear, this could serve to assess the possibility of suggesting it as an alternative gear to the traditional one.

Optimal soak time is a variable that fishermen should consider when evaluating the efficiency of the traps, to avoid leaving the gear less time than the working time, and avoid leaving it more time than necessary, considering the cost of the bait and the lack of profit (Zhou \& Shirley 1997). Other studies have also focused on the effective soak time with respect to the saturation percentage of the traps in some commercial crustaceans (Miller 1979, 1990; Zhou \& Shirley 1997, Vazquez-Archdale et al. 2007). Our results on the optimal time for trap saturation showed higher catches during the first hour of fishing, and a lack of increase in catches after the third hour; after the fifth hour the study species tended to escape (Fig. 4 and 5), suggesting that the optimum soak time for this particular fishing gear is 4.2 hours and no less than 2 hours. This same behavior was observed in the shore swimming crab Charybdis japonica and the blue swimming crab Portunus pelagicus by Vazquez-Archdale et al. (2007). They argued that catches usually tend to increase rapidly during the first hours of trap operation, and after some time the bait loses its attraction, which generates an adverse capture effect and the escape rate tends to increase. Our bait (sailfish skin) was the same bait used daily by the fishermen in CL.
It is possible that after the bait was gnawed and crushed by crabs, there was decreased attraction from the point of view of olfactory and visual stimulation, and therefore the organisms tended to escape (Miller 1979).

Although the traps selected larger individuals, it is important to evaluate the type, shape, position, and number of escape windows, and test different baits (De la RosaPacheco \& Ramírez-Rodríguez 1996, Herbert et al. 2001, Nevárez-Martínez et al. 2008, Cisneros-Mata et al. 2014).

Trap selectivity studies in Mexican crustacean fisheries will help fisheries managers determine gear configurations and soak times to optimize the selection of legal crabs while maximizing the escape of sub-legal crabs.

These types of studies could also serve to evaluate the possibility that crab catches obtained with traps could be used as an abundance index, with the knowledge and corrections of soak times (Miller \& Hunte 1987, Stiansen et al. 2008).

\section{ACKNOWLEDGMENTS}

We want to express our gratitude to the crab fishermen of Cuyutlan Lagoon, Mexico, for their support and teachings. We thank Domingo Brambila-López for his help during field work. We are grateful to INAPESCA (National Institute of Fisheries and Aquaculture) for the opportunity to carry out this study and to CONACyT (National Council of Science and Technology) for providing support through the program "Cátedras" (Project No. 2137: Strengthening academic capacities in the evaluation and management of fishery resources to tend to regional problems).

\section{LiTERATURE CITED}

Boutson A, C Mahasawasde, S Mahasawasde, S Tunkijjanukij \& T Arimoto. 2009. Use of scape vents to improve size and species selectivity of collapsible pot for blue swimming crab Portunus pelagicus in Thailand. Fisheries Science 75: 25-33.

Cisneros-Mata MÁ, E Ramírez-Félix, JA García-Borbón, V Castañeda-Fernández de Lara, A Labastida-Che, $C$ Gómez-Rojo \& J Madrid-Vera. 2014. Pesca de jaiba en el litoral del Pacífico mexicano, 86 pp. Instituto Nacional de Pesca, Ciudad de México.

CONAPESCA. 2017. Anuario estadístico de acuacultura y pesca, 300 pp. Comisión Nacional de Acuacultura y Pesca, SAGARPA, Ciudad de México.

Daniel WW. 1991. Bioestadística. Base para el análisis de las ciencias de la salud, 667 pp. Noriega-Limusa, Ciudad de México.

De la Rosa-Pacheco R \& M Ramírez-Rodríguez. 1996. Ventanas de escape en trampas para la captura de la langosta roja Panulirus interreptus en Baja California Sur, México. Ciencias Marinas 22(2): 235-243. 
Estrada-Valencia A. 1999. Aspectos poblacionales de la jaiba Callinectes arcuatus Ordway 1863, en la Laguna de Cuyutlán, Colima, México. Tesis de Magister, Facultad de Medicina Veterinaria y Zootecnia, Universidad de Colima, $77 \mathrm{pp}$.

Gil-López HA. 2009. Aspectos ecológicos, biológicos y pesqueros de las jaibas (Callinectes sp.) en el sistema lagunar Mar Muerto, Oaxaca-Chiapas, México. Tesis de Maestría en Ciencias, Área de Ciencias Biológico Agropecuarias y Pesqueras, Universidad Autónoma de Nayarit, Tepic, 89 pp.

Herbert M, G Miron, M Moriyasu, R Vienneau \& P DeGrace. 2001. Efficiency and ghost fishing of snow crab (Chionoecetes opilio) traps in the Gulf of St. Lawrence. Fisheries Research 52: 143-153.

Millar RB. 1992. Estimating the size-selectivity of fishing gear by conditioning on the total catch. Journal of the American Statistical Association 87(420): 962-968.

Millar RB \& RJ Fryer. 1999. Estimating the size-selection curves to towed gears, traps, nets and hooks. Reviews in Fish Biology and Fisheries 9: 89-116.

Miller RJ. 1979. Saturation of crab traps: reduced entry and escapement. Journal du Conseil / Conseil Permanent International pour l'Exploration de la Mer 38(3): 338-345.

Miller RJ. 1990. Effectiveness of crab and lobster traps. Canadian Journal of Fisheries and Aquatic Sciences 47: 1228-1251.

Miller RJ \& W Hunte. 1987. Effective area fished by Antillean fish traps. Bulletin of Marine Science 40: 484-493.

Montgomery DC. 1984. Design and analysis of experiments, 556 pp. John Wiley \& Sons, New York.

Nevárez-Martínez MO, A Balmori-Ramírez, E MirandaMier, JP Santos-Molina, FJ Méndez-Tenorio \& C Cervantes-Valle. 2008. Estructura de tallas, selectividad y composición específica de las capturas en trampas para peces marinos en el Golfo de California. Revista de Biología Tropical 56(3): 1403-1417.
R CoreTeam. 2020. R: A language and environment for statistical computing. R Foundation for Statistical Computing, Vienna. <https://www.R-project.org>

Rodríguez-Domínguez G, JA Félix-Ortíz \& R PérezGonzález. 2015. Autotomía de la jaiba café Callinectes bellicosus en una laguna costera de Sinaloa, México. Ciencia Pesquera 23 (especial): 35-42.

Rodríguez-Félix D, MÁ Cisneros-Mata, EA AragónNoriega \& JA Arreola-Lizárraga. 2016. Influencia de la proporción sexual y del ambiente en la tasa de crecimiento poblacional de Callinectes bellicosus (Decapoda: Portunidae) del Golfo de California. Revista de Biología Tropical 64(3): 1259-1271.

Sosa-Ávalos R, G Gaxiola-Castro, A Olivos-Ortiz \& L SilvaIñiguez. 2013. Nutrientes inorgánicos y producción del fitoplancton en una laguna costera subtropical de México. Revista de Biología Marina y Oceanografía 48(1): 143-154.

Stewart J \& DJ Ferrell. 2003. Mesh selectivity in the New South Wales demersal trap fishery. Fisheries Research 59: 379-392.

Stiansen S, A Fernö, D Furekiv, T Jørgensen \& S Løkkeborg. 2008. Efficiency and catch dynamics of collapside square and conical crab pots used in the red king crab (Paralithodes camtschaticus) fishery. Fishery Bulletin 106: 40-46.

Vazquez-Archdale M, C Pilapil-Añasco, Y Kawamura \& S Tomiki. 2007. Effect of two collapsible pot designs on escape rate and behavior of the invasive swimming crabs Charybdis japonica and Portunus pelagicus. Fisheries Research 85: 202-209.

Zar JH. 1996. Biostatistical analysis, 662 pp. Prentice Hall, Upper Saddle River.

Zhou S \& TC Shirley. 1997. A model expressing the relationship between catch and soak time for trap fisheries. North American Journal of Fisheries Management 17: 482-487. 